Yuliia Pavlenko, Candidate of Pedagogical Sciences, Poltava National V. G. Korolenko Pedagogical University, 2, Ostrogradsky str., Poltava, 36000, Ukraine ORCID: 0000-0001-7430-9869; ResearcherID: AAH-2170-2020

\title{
EXTENDING THE OUTLOOK OF THE FUTURE TEACHER WITH THE HELP OF MUSEUM MEANS
}

The article shows the possibilities of using museum-pedagogical information in the content of future teachers' professional training. The ways of introduction of the museum-pedagogical component in the context of the main types of activities of students in higher education with consideration of the pedagogical specialty are proposed and their effectiveness is determined.

Keywords: outlook, museum, museum pedagogy, museum information, professional training of future teachers.

\section{Relevance of research topic.}

The training of a highly qualified teacher is a problem not only for the higher pedagogical school but also for the society and the state as a whole. Each country is interested in preparing a galaxy of new education teachers who would be able to provide not only a quantitative fulfillment of compulsory education tasks but also raise the level of education and culture of its citizens.

Modern society sees the role of education in the comprehensive development of the individual, one of the important characteristics of which is a broad outlook. This is especially true of the teacher, who should be a role model for his students, a man of encyclopedic knowledge, which he is constantly updating and improving. In addition, the teacher directly affects the level of development of their students, as well as their outlook.

\section{Formulation of the problem.}

One of the resources for improving the professional training of future educators, both in content and in results, may be the use of museum facilities, because «a museum is a unique space saturated with a high power of informational and emotional interaction, built on the principles of dialogue of cultures separated in time and space. Due to its intrinsic traits, it has exceptional potential for influencing the individual, shaping his or her outlook and spirituality» (Stolyarov, 2004). 


\section{Analysis of recent researches and publications.}

Well-known Ukrainian theorists and practitioners of pedagogical education (O. Bondarevskaya， V. Galuzynsky， M. Grinyova， M. Yevtukh， E. Zakharchenko, I. Ziazun, I. Prokopenko, L. Khomich, and other scientists) point to the numerous advantages of forming new generations of educators in the cultural environment, including the museum. They emphasize the development of the general and pedagogical culture of future teachers, as the basis of professional self-assertion and self-realization of the future specialist.

For the modern stage of educational development, the revival of the tradition of working with children and young people on the basis of museum collections in accordance with age and educational needs has become noticeable. There is an active development of museum pedagogy - a «pedagogical discipline that studies ways of developing a humanistic worldview based on spiritual values, as well as the specifics of the intellectual, ethical and aesthetic development of the individual in the process of museum communication» (Udovichenko, 2017).

It is reasonable to think that the museum environment, filled with deep value content, deserves widespread use in educational practice, including the educational environment of a pedagogical institution of higher education. Some studies at the scientific level proved the effectiveness of the use of museums in the process of professional education of future educators: E. Hooper-Greenhill (2007) presented the modernist experience of foreign scientists conducting training sessions with schoolchildren and students in the museum environment; O. Karamanov (2014) presented as an alternative to the classroom-teaching system, an educational space that promotes the involvement of museums in the processes of continuous integration of knowledge, stimulates the development of the tourism industry and leisure, alters the psychological setting of the individual in the learning process as an important factor in their own development; N. Karapuzova, Y. Pavlenko (2018) substantiated the effectiveness of the use of museums of pedagogical profile in the professional training of future elementary school teachers; I. Melnychuk (2017) analyzed the method of using museum pedagogy in the professional training of future teachers of natural sciences.

Despite the aforementioned scientific and theoretical achievements, in practice museum funds are not yet sufficiently used in the professional training of future teachers. It requires focused, systematic and consistent work on the use of museum potential for the professional development of future teachers, including the broadening of their outlook.

The purpose of the publication is to analyze the possible ways of introducing museum information into the content of future teachers' professional training and to determine the effectiveness of the museum-pedagogical component in the context of the student's main activities while studying at a pedagogical institution of higher education. 


\section{Presenting main material.}

The Dictionary of Ukrainian Language (2018) gives such definition of the concept of «outlook» - the volume, breadth of ideas, knowledge, interests. The breadth of a person's outlook, therefore, depends on the level of mastery of literacy, education, and upbringing, which undoubtedly affects the value orientations and behavior of the person in the future.

Object-by-nature, a museum environment filled with deep value content and specially adapted for perception by different categories of educational recipients, deserves widespread use in educational practice, including the pure and educational space of vocational and pedagogical education.

The advantages of expanding the outlook of future educators in the museum environment, in comparison with the traditional one, seem to us obvious: since different types of professional competences a student acquires not only in the study of academic disciplines, not only in the process of interpersonal communication, but also due to the influence of the subject world, which is away from the subject world.

Immersion of the pedagogical profession into the world of culture is easy and especially easy in the museum, where there are unique opportunities to influence all the diversity of feelings. It is as a result of such a combination that adequate cultural identification of the individual, transformation of cultural customs and formation of moral attitudes occurs. Thus the museum becomes a platform for dialogue of epochs, cultures, peoples, and the future educator - the active participant of these processes, thus expanding its outlook.

Traditionally, for all pedagogical disciplines, common subject-oriented sources of content are defined: current normative documents, classical and modern pedagogical theories, concepts, domestic and foreign pedagogical journalism, works of eminent representatives of education and school, as well as electronic resources, electronic platforms, (Sadovaya, 2016, p. 52].

That is, the printed word is the most common and at the same time abstract means of conveying information and mastering educational content.

The method of transmission and capture of museum information is quite specific. It is concentrated in a kind of museum environment. Its main information and resource unit is the museum object - a phenomenon that has the characteristics of uniqueness and historicity, which can be considered as a cultural object in general, as the primary source of scientific knowledge and as a special effective means of pedagogical influence.

Information potential of a museum object is formed by the synthesis of sociological, semiotic, psychological and applied models of communication. At the same time it is both material and spiritual carrier of various data on the shape, color, size, weight, origin, methods of manufacture, features of life, the owner of the object, the tradition, beliefs and even feelings of people, etc. 
V. Sabov (2015), comparing the traditional way of transforming information (letter-reading) with the so-called «museum» (using real things and exposition messages, illustrations), emphasizes the advantages of the latter. The author emphasizes that museum objects are a special kind of sources where information is encoded differently than in written documents; "As a monument of history and culture, a museum object is always directly involved in the historical process, being part of it, giving meaningful first-hand information.»

In our opinion, the use of museum-pedagogical information in the content of future teachers' professional training should be carried out in the context of the content of the main activities in higher education (educational, scientific, educational), take into account the specialties and specialization, which is mastered by the student.

Thus, during the study of different academic disciplines and during the classroom, independent work, students perform the task of working on museum collections; Teachers build the content of lectures, seminars, practicals and laboratory classes using museum exposition (or individual museum items) as a means of identifying and interpreting the content of professional disciplines.

In the context of research activities, the implementation of research tasks on the materials of museums is envisaged; selection of materials for abstracts, coursework, diploma papers, articles, reports in museum collections and during search expeditions; participation in scientific conferences, student groups working at museums or discovering museum-pedagogical topics.

Undertaking educational activities in the museum environment for the purpose of professional-psychological, patriotic, ethical, aesthetic, moral, spiritual, ecological, national upbringing of students, of course, has high efficiency and is marked not only by a fruitful but also fascinating manifestation of university life.

Particularly positive is the introduction of free choice of students - modern and progressive - «Museum Pedagogy» into the curriculum of future teachers of the discipline (at the Korolenko National Pedagogical University of Poltava, taught since 2017-2018 on the speciality of «Primary Education» (V. G. Korolenko PNPU, 2017). This discipline helps future primary school teachers to understand the importance of museum influence on harmonic development of children of primary school age, reveals the theoretical and methodological principles of museum and educational activities in schools and highlights the museum and excursion opportunities of the hometown.

Experimentally, it has been proven that the use of the museum component contributes to the improvement of the professional training of future teachers as a whole, and in particular the widening of the students' outlook.

The basis of the experimental base was the museum complex of the Poltava National Pedagogical University named after V. G. Korolenko. Independent museums of Poltava city, separate museums of educational establishments of I-III degrees of Poltava and electronic museum communications were also used during the experiment. 
The experiment involved the introduction of a system of use of the museum component in the professional training of future teachers through the implementation of specially developed technology, which is complex in nature and requires constant step-by-step implementation of pedagogically expedient measures (forms, methods and techniques) in the classroom and extracurricular work. In particular, there were explanatory discussions aimed at understanding the role of museums in their personal and professional development; future teachers were involved in a variety of activities in the museum environment, which required a research and creative search position. For example, in the course of studying general pedagogical disciplines and professional techniques, teachers, together with museum educators, conducted a series of museum excursions, during which future teachers were involved in discussing the exposition, stimulating judging of all new things they saw and learned.

Due to the overwhelmingly strong interest of the experimental group students in the achievements of national and world culture, in our opinion, it is natural to expand their horizons. This indicator was established with the help of a specially designed questionnaire, where students were asked 100 questions regarding ideas, concepts, facts about outstanding personalities, objects and phenomena of nature, cultural life that can be learned, especially in museums.

The data obtained in the course of the research indicate that the outlook of future teachers of the experimental group has significantly expanded in the museums. Thus, at the final stage of the study there were $9.7 \%$ of students who were able to score more than 60 points during the survey, and at the control level $-74.8 \%$. The control group also experienced positive changes in this indicator, but the increase is much smaller than in the experimental group $-37.8 \%$ versus $65.1 \%$.

The graphical representation of the dynamics of the latitude of the horizon according to the results of the study is presented by the method of constructing the histogram in Figure 1.

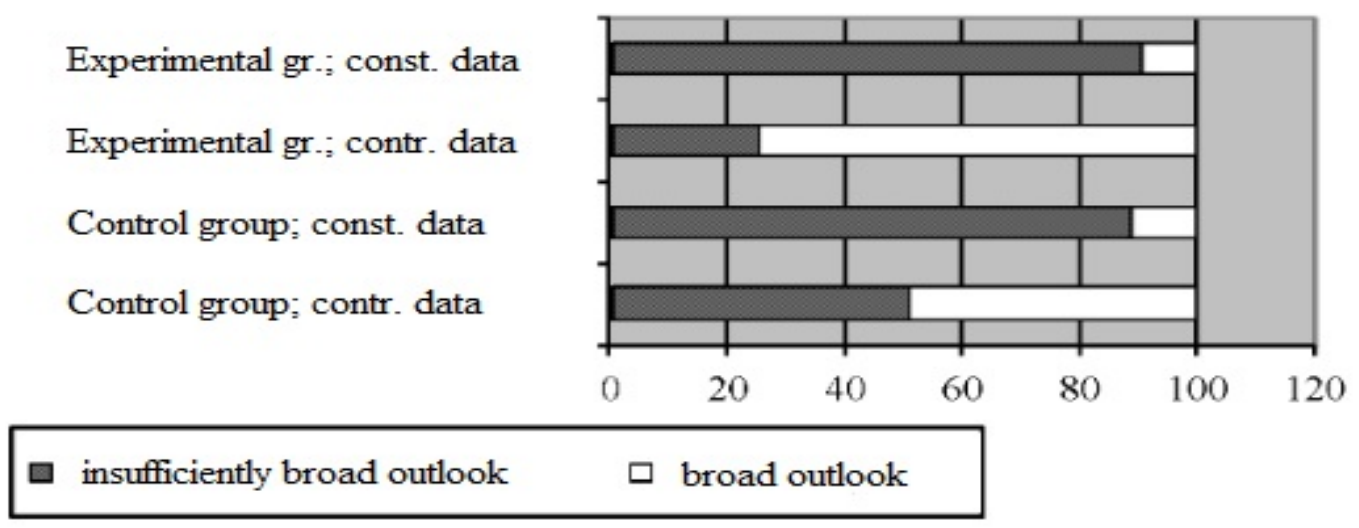

Fig. 1. Dynamics of the latitude of students of experimental and control groups during the study. 
As the diagnostic results show, the students of the experimental group were more aware of the historical figures of their native land. This indicates the future teachers' preparedness for self-development and their own outlook.

Conclusion. Thus, the introduction of a museum component in the structure of future teachers' professional training will provide an extension of students' outlook and promote their spiritual self-improvement, formation of intellectual and cultural potential as the highest value of society.

\section{REFERENCES}

1. Dictionary of the Ukrainian language. Academic Interpretive Dictionary (1970-1980). (2018). Retrieved from: http://sum.in.ua/s/krughozir

2. Disciplines of free selection of students of the psychological-pedagogical faculty of recruitments 2017. (2017). Poltava National V. G. Korolenko Pedagogical University. Faculty of Psychology and Pedagogy. Retrieved from: http://ped.pnpu.edu.ua/poch_opus.pdf

3. Hooper-Greenhill, E. (2007). Museums and Education: Purpose, Pedagogy, Performance. London and New York.

4. Karamanov, O. V. (2014). Educational potential of museum pedagogy: dialogue, communication, creativity. Bulletin of the Lviv Commercial Academy. Series: Humanities, 12, 242-246. Retrieved from: http://nbuv.gov.ua/UJRN/ Vlca_Gum_2014_12_32

5. Karapuzova, N. D., \& Pavlenko, Yu. H. (2018). Museums of pedagogical profile in the vocational training of future primary school teachers. In O. V. Lobova, \& I. P. Rohalska-Iablonska, (Ed.), Education and upbringing of preschool and primary school children in the challenges of today (pp. 373-392). Sumy: FOP Tsoma S. P.

6. Melnychuk, I. M. (2017). The use of museum pedagogy in the professional training of future teachers of natural sciences. Zbirnyk naukovykh prats Natsionalnoi akademii Derzhavnoi prykordonnoi sluzhby Ukrainy. Seriia : Pedahohichni nauky, 2(9), 233-242.

7. Sabov, M. M. (2015). Museum exposition as a kind of scientific publication. DNIM imeni D. I. Yavornytskyi. Retrieved from: http://museum.dp.ua/ article_2015_52.html

8. Sadova, V. V. (2016). Fundamentalisation of the content of pedagogical disciplines in the preparation of future primary school teachers: theoretical and methodological aspects. Kryvyi Rih: R. A. Kozlov.

9. Stolyarov, B. A. (2004). Museum pedagogy. History, theory, practice. Moskva: Vysshaya shkola.

10. Udovychenko, I. V. (2017). Museum pedagogy: theory and practice. Kyiv: Lohos, Natsionalnyi muzei istorii Ukrainy. 